
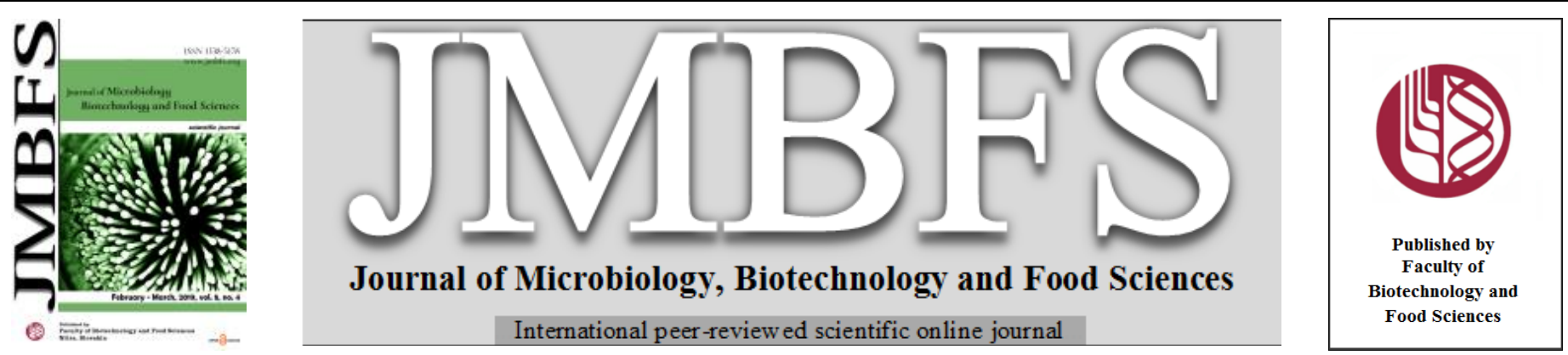

\title{
IMPROVEMENT OF PHYTASE BIOSYNTHESIS BY NEW BACTERIAL ISOLATE, Pediococcus pentosaceus C4/1A VIA CONTINUOUS CULTIVATION
}

\author{
Sasirega Raman ${ }^{1}$, Norhani Abdullah ${ }^{2}$, Liang Juan Boo ${ }^{2}$,Susan Azizi ${ }^{1}$, RosfarizanMohamad*1
}

Address(es): Associate Professor Dr. Rosfarizan Mohamad,

1Universiti Putra Malaysia, Faculty of Biotechnology and Biomolecular Sciences, Department of Bioprocess Technology, 43400 UPM Serdang, Selangor, Malaysia, $+60-1-3263-6029$.

2 Universiti Putra Malaysia, Institute of Tropical Agriculture, Animal Production Laboratory, 43400 UPM Serdang, Selangor, Malaysia.

*Corresponding author: farizan@upm.edu.my

doi: 10.15414/jmbfs.2019.8.5.1118-1124

\section{ARTICLE INFO}

Received 27. 3. 2018

Revised 3. 11. 2018

Accepted 20. 11. 2018

Published 1. 4. 2019

Regular article

OPEN ${ }_{\text {ACCESS }}$

\begin{abstract}
Phytase producer was selected from five different lactic acid bacteria isolates obtained from the animal faeces sources from laboratory culture collection. From the five isolates, C4/1 A showed the highest phytase activity $(21.25 \mathrm{U} / \mathrm{mL})$ as compared to others and was identified as PediococcuspentosaceusC4/1A by 16S rRNA gene sequencing. Optimization of medium formulation and culture conditions was conducted by a conventional method (one-factor-at-one-time) using response surface methodology(RSM). Effects of four parameters were studied on the bacterial growth, reducing sugar and phytase productions. The phytase biosynthesis increased from $21.2 \mathrm{U} / \mathrm{mL}$ to $42.3 \mathrm{U} / \mathrm{mL}$ using the optimized medium formulation and culture conditions. The RSM suggested that yeast extract, glucose, sodium phytate and inoculum size significantly improved by $99.2 \%$ production of phytase. Continuous cultivation was carried out at dilution rate ranging from $0.1 \mathrm{~h}^{-1}$ to $0.4 \mathrm{~h}^{-1}$ and the steady-state of $P$. pentosaceusC4/1A was achieved after five generations and three residence times. The cultivation was carried out for $48 \mathrm{~h}$ and the highest productivity of phytase and cell concentration was obtained at dilution rate $0.3 \mathrm{~h}^{-1}$ which resulted in $8.65 \mathrm{U} / \mathrm{mL} / \mathrm{h}$ and $0.894 \mathrm{~g} / \mathrm{L} / \mathrm{h}$, respectively. Throughout the cultivation process, production of phytase was improved by $89.3 \%$ from shake-flask experiment to $2 \mathrm{~L}$ bioreactor.
\end{abstract}

Keywords: lactic acid bacteria, optimization, response surface methodology, bioreactor, high productivity

\section{INTRODUCTION}

Phytate is known as myo-inositol hexakisphosphate. Phytate can be found in cereals, maize, nuts and legume (Lönnerdal, 2002). It accounts up to $80 \%$ of total phosphorus in plant seeds and used commercially in animal feeds. The main function of phytate is to act as an inhibitor or also known as an anti-nutritional factor, where it inhibits the absorption of vitamins and minerals in the gastrointestinal tract of monogastricanimals(Lopez et al., 2002; Lazarte et al., 2015). One of the reasons that phytate is difficult to be digested by monogastric animals is due to lack of phytase activity in their digestive system. Besides, quality of animal feed reduced since phytate forms complexes with minerals and also other divalent cations such as calcium, magnesium and zinc (Mittal et al., 2012a). The undigested phytate phosphorus excreted by monogastric animals were used as fertilizers for plants which later consequently contributes to the phosphorus pollution and causes problems in the area of intensive livestock production (Haehner et al., 2005 and Bohn et al.,2008a). Regarding the environmental issues, it was then proposed that the addition of inorganic phosphate in animal feed will help to overcome the problems. Since the addition of inorganic phosphate increases the cost of diets, an alternative method was carried out by using microbial phytase. Lactic acid bacteria was chose in this study as they have probiotic properties and potential to degrade phytate such as in fermented food processes including dairy and non-dairy products (De Angelis et al., 2003a). It can be found in water, sewage, soil and manure (Holzapfel et al., 2001). Lactic acid bacteria (LAB) can be classified as homofermentatives where hexoses are catalysed to lactose or heterofermentatives where $\mathrm{LAB}$ degrades hexases to lactate and additional products. LAB is classified based on its $16 \mathrm{~S}$ rRNA gene sequencing which has a G + C content below $50 \mathrm{~mol} \%$ (Savadogo e al.,2006). LAB are safe to be used due to its long history in food fermentation and are also known as Generally Recognized as Safe (GRAS) microorganism that capable to produce phytase enzyme (Ammor et al., 2007). LAB are defined as microbial food supplements by Food and Agriculture Organization of the Oriental Nations and WHO (Araya et al., 2002) due to its beneficial property to the health of host. In industrial application, LAB plays the major rule for production of fermented foods, to manufacture probiotic products, metabolites for the purpose of texture and flavor development and also health applications (Papagianni, 2012).Phytase can be found in fungi, yeast, bacteria, animals and plants (Greiner et al., 2007). As reported by (Zhang et al.,2013)phytase can also be found in mushrooms. The use of phytase in human nutrition creates a good potential in manufacturing and processing food. In addition, the use of phytase enzyme to solve the eutrophication problem was said to reduce up to $50 \%$ by supplementing phytase in animal diets. It is also reported that phytase increases the bioavailability in digestive system of monogastric animals (Roy et al., 2009). Production of phytase from various microorganisms can be induced by the presence of phytate(Marlida et al., 2010) or by agro-waste product such as orange peel and wheat bran (Mittal et al., 2012b). A study conducted by (Raghavendra and Halami, 2009a), reported that Pediococcuspentosaceus strains (CFR R38 and CFR R35) were able to degrade sodium phytate as its main phosphate source and showed phytase activity at $50^{\circ} \mathrm{C}$. A part from that, good formulation of medium and culture conditions will also enhance the production of phytase enzyme during fermentation. Response surface methodology (RSM) which was introduced by (Box and Wilson, 1951) is a statistical and mathematical technique used in experiments to increase the productivity by optimizing the independent variables used. Continuous cultivation is a technique where it has been used in industries for processes such as ethanol production, single cell protein production, and vinegar production. It has not been used in laboratory scale unless for the study of physiology and growth of microorganisms. Application of continuous cultivation with the microbial population was developed by (Monod, 1950; Novickand Szilard, 1950) Throughout the cultivation, the working volume is maintained at a constant level and the steady state of the microorganisms can be achieved (CatarinaGuedes et al., 2013). Other parameters such as temperature, $\mathrm{pH}$ and dissolved oxygen can also be controlled by the researcher itself according to the conditions applied. Experiments can be designed and growth factors can be optimized to achieve the maximum yield of desired products (Myers et al., 2009a). The aim of the present study was to improve the production of phytase enzyme by optimizing medium formulation and culture conditions through the conventional method, statistical technique of RSM and continuous cultivation. 


\section{MATERIAL AND METHODS}

\section{Collection of Lactic Acid Bacteria}

The samples used in this study were isolates of lactic acid bacteria (LAB) which was taken from the Laboratory culture collection, Bioprocess Technology Laboratory at the Faculty of Biotechnology and Biomolecular Sciences, Universiti Putra Malaysia (Tan, 2016a). Isolates were further identified by molecular techniques by partial sequencing of $16 \mathrm{~S}$ rRNA.

\section{Inoculum Preparation}

The inocula from glycerol stock was thawed and streaked on DifcoMRS agar plate. The plate was incubated at $37^{\circ} \mathrm{C}$ for $24 \mathrm{~h}$. A single colony was picked and transferred into a test tube containing $10 \mathrm{~mL}$ of DifcoMRS broth medium Theinoculated broth was incubated at $37^{\circ} \mathrm{C}$ overnight. Then the strain inoculum of $10 \%(\mathrm{v} / \mathrm{v})$ was prepared in $250 \mathrm{~mL}$ Erlenmeyer flask containing $100 \mathrm{~mL}$ of MRS broth. The inoculum culture was incubated at $37^{\circ} \mathrm{C}$ for $16 \mathrm{~h}$ withou agitation in an incubator (Protech Shaker Incubator Model SI-100D). As the sample has reached OD reading of 0.6 , the inoculums was used for cultivation.

\section{Production Medium}

The isolates were cultivated in modified MRS medium whereby inorganic phosphate $\left(\mathrm{K}_{2} \mathrm{HPO}_{4}\right)$ was replaced with $0.65 \mathrm{~g} / \mathrm{L}$ of sodium phytate as phosphate source and 0.1M 3-[N-Morpholino] propanesulfonic acid (MOPS). The amount of glucose, yeast extract and meat extract were reduced to 10,2 and $4 \mathrm{~g} / \mathrm{L}$, respectively. The flasks were incubated in an incubator shaker at $150 \mathrm{rpm}$ at $37^{\circ} \mathrm{C}$ for $24 \mathrm{~h}$ (Raghavendra and Halami, 2009b).

\section{Screening for the Best Phytase Producing Bacteria}

Isolated bacteria from animal feces were screened for phytase production on modified MRS agar. The qualitative screening was carried out by observing the clear halo zone and colony diameters were measured after $24 \mathrm{~h}$ of incubation at $37^{\circ} \mathrm{C}$ (Raghavendra and Halami, 2009c), which shows the minimum clear zone of $1.7 \mathrm{~cm}$ and the maximum clear zone of $4.0 \mathrm{~cm}$.

\section{Quantitative Assay of Phytase Production}

Phytase activity was quantified by adding $150 \mu \mathrm{l}$ of cell suspension to $600 \mu$ $0.2 \%(\mathrm{w} / \mathrm{v})$ sodium phytate prepared in $0.1 \mathrm{M}$ sodium acetate buffer $(\mathrm{pH} 5.0)$. The reaction mixture was incubated for 20 minutes at $37^{\circ} \mathrm{C}$. Stop reagent, $5 \%(\mathrm{w} / \mathrm{v})$ trichloroacetic acid (TCA), was added right after the incubation. The liberated phosphate ions were quantified by mixing 4 volumes of $1.5 \%(\mathrm{w} / \mathrm{v})$ ammonium molybdate solution in $5.5 \%(\mathrm{v} / \mathrm{v})$ sulfuric acid to 1 volume $2.7 \%(\mathrm{w} / \mathrm{v})$ ferrous sulfate solution. Absorbance was measured at a wavelength of $700 \mathrm{~nm}$ after incubation for 5 minutes of the color development period. One enzyme unit (U) was defined as the amount of enzyme liberating $1 \mu \mathrm{mol}$ of inorganic phosphate in 1 minute under the assay conditions (Yanke et al., 1998).

\section{Conventional Method}

Production medium was prepared in $250 \mathrm{~mL}$ Erlenmeyer flasks and inoculated with $10 \%(\mathrm{v} / \mathrm{v})$ inoculum. The selected strain was optimized on medium formulation and culture conditions for phytase production at $37^{\circ} \mathrm{C}$ for $24 \mathrm{~h}$ in incubator shaker. A volume of $5 \mathrm{~mL}$ of samples was withdrawn at time intervals for analysis of phytase activity, cell concentration and reducing sugar.

\section{One-factor-at-a-time}

Different parameters and concentrations of medium formulation and culture condition via one-factor-at-a-time experiments (Vohra and Satyanarayana, 2001) are shown in Table 1. All the experiments were carried out in triplicates and the results were reported as the mean of the replicates.

Table 1Parameters and variables used in one-factor-at-a-time approach

Parameter Variables/Concentration

\begin{tabular}{lc}
\hline A. Carbon Source & Glucose, Lactose, Maltose $(10 /(\mathrm{g} / \mathrm{L}))$ \\
B. Glucose & $5,10,15,20(\mathrm{~g} / \mathrm{L})$ \\
C. Nitrogen Source & Yeast extract, Meat extract, Peptone from \\
D. Yeast extract & Casein $(15 /(\mathrm{g} / \mathrm{L}))$ \\
E. Sodium phytate & $5,10,15,20,25(\mathrm{~g} / \mathrm{L})$ \\
F. Inoculum size & $4,5,10,15,20(\mathrm{~g} / \mathrm{L})$ \\
\hline
\end{tabular}

Experimental Design and Data Analysis

The experimental design was conducted according to variables from one-factorat-a-time. Between the three carbon sources (glucose, lactose and maltose) and three nitrogen sources (yeast extract, meat extract and peptone from casein) tested, glucose and yeast extract was chosen as the independent variable including sodium phytate and inoculum size. An optimization study was conducted by Response Surface Methodology using Central Composite Design (CCD). The response of interest was phytase activity (Y). The experiment was conducted at three different levels $(+1,0,-1)$ as shown in Table 2 and a total of 30 runs were conducted. The experimental values and predicted values of phytase production are shown in Table 3. A second order polynomial was conducted for all the four variables using multiple regression analysis. The model equation is as shown below:

$Y=\beta_{0}+\beta_{1} A+\beta_{2} B+\beta_{11} A^{2}+\beta_{22} B^{2}$

$+\beta_{33} \mathrm{C}^{2}+\beta_{44} \mathrm{D}^{2}+\beta_{12} \mathrm{AB}+\beta_{13} \mathrm{AC}$

$+\beta_{14} \mathrm{AD}+\beta^{23} \mathrm{BC}+\beta_{24} \mathrm{BD}+\beta_{34} \mathrm{CD}$

Where Y, predicted response; $\beta_{0}$ intercept; $\beta_{1}, \beta_{2}$ linear coefficients; $\beta_{11}, \beta_{22}, \beta_{33}$ $\beta_{44}$ squared coefficients; $\beta_{12}, \beta_{13}, \beta_{14}, \beta_{23}, \beta_{24}, \beta_{34}$ interaction coefficients.

Statistical software package Design Expert 6.0 was used to analyze the experimental design based on response surface methodology. The optimum value of independent variables was determined coefficient, correlation coefficient and statistical testing of the model. Besides that, the significant value of the model, determination of regression value and analysis of variance (ANOVA) was also identified (Myers et al., 2009b).

Table 2Three levels of factor used for independent variables in CCD

\begin{tabular}{clccc}
\hline \multirow{2}{*}{ Variables } & \multicolumn{1}{c}{ Factors } & \multicolumn{3}{c}{ Actual value of coded factors } \\
\cline { 3 - 5 } & & -1 & 0 & +1 \\
\hline $\mathrm{A}$ & Inoculum size $(\%)$ & 5 & 7.5 & 10 \\
$\mathrm{~B}$ & (Sodium Phytate) $/(\mathrm{g} / \mathrm{L})$ & 5 & 10 & 15 \\
$\mathrm{C}$ & (Yeast extract) $/(\mathrm{g} / \mathrm{L})$ & 10 & 15 & 20 \\
$\mathrm{D}$ & (Glucose) $/(\mathrm{g} / \mathrm{L})$ & 10 & 15 & 20 \\
\hline
\end{tabular}

Table 3 Experimental design used for the optimization studies on phytaseproduction

\begin{tabular}{|c|c|c|c|c|c|c|}
\hline \multirow{2}{*}{ Run } & \multicolumn{4}{|c|}{ Variables } & \multicolumn{2}{|c|}{ (Phytase activity)/(U/mL) } \\
\hline & $(\mathrm{A}) /(\%)$ & (B) $/(\mathrm{g} / \mathrm{L})$ & $(\mathrm{C}) /(\mathrm{g} / \mathrm{L})$ & (D) $/(\mathrm{g} / \mathrm{L})$ & Experimental & Predicted \\
\hline 1 & 7.5 & 10 & 15 & 15 & 41.58 & 41.56 \\
\hline 2 & 7.5 & 10 & 15 & 10 & 40.31 & 40.37 \\
\hline 3 & 7.5 & 10 & 20 & 15 & 40.00 & 39.93 \\
\hline 4 & 7.5 & 10 & 15 & 15 & 41.33 & 41.56 \\
\hline 5 & 7.5 & 5 & 15 & 15 & 41.89 & 41.67 \\
\hline 6 & 10 & 15 & 20 & 20 & 41.50 & 41.42 \\
\hline 7 & 5 & 5 & 10 & 10 & 40.31 & 40.33 \\
\hline 8 & 7.5 & 10 & 15 & 15 & 41.58 & 41.56 \\
\hline 9 & 5 & 5 & 20 & 10 & 39.46 & 39.37 \\
\hline 10 & 10 & 5 & 20 & 10 & 40.17 & 40.16 \\
\hline 11 & 7.5 & 10 & 15 & 15 & 41.57 & 41.56 \\
\hline 12 & 7.5 & 15 & 15 & 15 & 42.39 & 42.57 \\
\hline 13 & 7.5 & 10 & 15 & 15 & 41.58 & 41.56 \\
\hline 14 & 5 & 15 & 10 & 10 & 42.34 & 42.24 \\
\hline 15 & 10 & 15 & 10 & 10 & 39.43 & 39.31 \\
\hline 16 & 10 & 10 & 15 & 15 & 42.47 & 42.42 \\
\hline 17 & 7.5 & 10 & 15 & 15 & 41.58 & 41.56 \\
\hline 18 & 5 & 15 & 20 & 10 & 40.29 & 40.41 \\
\hline 19 & 10 & 15 & 20 & 10 & 39.46 & 39.43 \\
\hline 20 & 5 & 10 & 15 & 15 & 42.13 & 42.14 \\
\hline 21 & 10 & 5 & 20 & 20 & 41.37 & 41.53 \\
\hline 22 & 10 & 15 & 10 & 20 & 40.38 & 40.54 \\
\hline 23 & 5 & 5 & 10 & 20 & 38.14 & 38.24 \\
\hline 24 & 7.5 & 10 & 10 & 15 & 39.94 & 39.97 \\
\hline 25 & 7.5 & 10 & 15 & 20 & 40.43 & 40.32 \\
\hline 26 & 5 & 15 & 10 & 20 & 40.82 & 40.77 \\
\hline 27 & 5 & 15 & 20 & 20 & 39.80 & 39.71 \\
\hline 28 & 10 & 5 & 10 & 20 & 39.96 & 39.78 \\
\hline 29 & 10 & 5 & 10 & 10 & 39.03 & 39.18 \\
\hline 30 & 5 & 5 & 20 & 20 & 37.97 & 38.04 \\
\hline
\end{tabular}

Legend: A: Inoculum Size, B: Sodium Phytate, C: Yeast Extract, D: Glucose

\section{Batch Cultivation in 2L Stirred Tank Bioreactor}

The experiments on batch cultivation were carried using $2 \mathrm{~L}$ stirred tank bioreactor (Biostat, B. Braun, Melsungen, Germany). The bioreactor comprised of borosilicate glass culture vessel with outer thermostat jacket. It consists of software and hardware control systems which are dissolved oxygen, $\mathrm{pH}$ and temperature probe. In addition, there are also acid, base and antifoam ports, sampling port and inoculation port. The agitation was provided with the usage of two six-bladed turbine impellers and other variables. During the cultivation, agitation speed was set at a constant rate of $150 \mathrm{rpm}$ under aseptic condition. The working volume of $600 \mathrm{~mL}$ was prepared in the bioreactor and inoculated with $10 \%(\mathrm{v} / \mathrm{v})$ of inoculum. The cultivation process was carried out with an initial $\mathrm{pH}$ 
of 6.2. Throughout the cultivation period, $\mathrm{pH}$ was not controlled and the temperature was set at $37^{\circ} \mathrm{C}$ within the vessel.

\section{Continuous Cultivation in 2L Stirred Tank Bioreactor}

Continuous cultivation was carried out using different range of dilution rate (D) which starts from $0.1,0.2,0.3$ and $0.4 \mathrm{~h}^{-1}$. Inoculum was prepared in $250 \mathrm{~mL}$ Erlenmeyer flask containing $100 \mathrm{~mL}$ of medium and inoculum size of $10 \%(\mathrm{v} / \mathrm{v})$ was inoculated into $600 \mathrm{~mL}$ of working volume in the bioreactor. The continuous cultivation took place for $48 \mathrm{~h}$ and the productivity of enzyme and cell concentration was observed throughout the fermentation. In this system, a growth of microorganisms is determined by dilution rate and limiting substrate concentration. The relationship between the rates of medium flow into the reactor-related to its culture volume is well explained by the dilution rate (D) as expressed in units per hour $\left(\mathrm{h}^{-1}\right)$.

$\mathrm{D}=\mathrm{F} / \mathrm{V}$

where $\mathrm{F}$ is the flow rate $\left(\mathrm{Lh}^{-1}\right)$ and $\mathrm{V}$ is the culture volume expressed in $\mathrm{L}$.

A steady-state of the microorganisms in the continuous cultivation is usually achieved after three or five generation time. The change in substrate concentration $(\mathrm{S})$ over time $(\mathrm{t})$ and the change in biomass $(\mathrm{X})$ over time are equal to zero, which means there is no net accumulation of substrate or cell biomass. $\mathrm{dS} / \mathrm{dt}=0$ or $\mathrm{dX} / \mathrm{dt}=0$

The specific growth rate $(\mu)$ of the culture in steady state is related to the dilution rate (D). This can be said that, as the dilution rate is higher than the maximum specific growth rate $\left(\mu_{\max }\right)$, the cells in the vessel will be washed out. The biomass equation can be used for the continuous cultivation:

$\mathrm{dX} / \mathrm{dt}=\mu \mathrm{X}-\mathrm{DX}$

When the cells in the vessels are washed out, there will be less number of cells in the bioreactor and becomes zero over time (McNeil and Harvey, 2008).

\section{Analytical Method}

Every $2 \mathrm{~h}$ of the time interval, the samples were collected and centrifuged a $2700 \mathrm{x} g$ for $15 \mathrm{~min}$. The supernatant collected was kept in a clean test tube to be used for determination of substrate concentration by DNS reagent (Miller et al., 1960), whereas cell concentration was expressed as dry cell weight per culture volume was obtained by filtration and oven drying method and total protein content was measured by (Lowry et al.,1951). In addition, cell pellet obtained was used to determine the phytase activity (Raghavendra and Halami, 2009d).

\section{RESULTS AND DISCUSSION}

\section{Screening, Isolation, and Identification of Phytase Producer}

From the study, a total of 41 isolates were obtained from the isolation process Five isolates were identified as lactic acid bacteria in Figure 1 which shows the clear halo zone obtained around the colony during qualitative screening. This is due to the hydrolysis of phytate by lactic acid bacteria, which was a similar experiment done by (De Angelis et al., 2003b). The plates were then stained with cobalt chloride solution, which helps to determine the false positive results. Sodium phytate plays the role as phosphate source in modified MRS agar which induces the production of phytase. All the tested isolates showed positive results of phytate-degrading ability, however, only one isolate labeled as D (C4/1A) showed the largest zone of hydrolysis, compared to other isolates. This could be due to the presence of phytate specific enzyme known as phytase. When phytase is produced, phytic phosphorus is cleaved and a free hydroxyl group is produced Cobalt chloride binds to a free hydroxyl group and phytin remains unchanged (Baeet al., 1999). Hence, the addition of ammonium molybdate and ammonium metavanadate binds to cobalt chloride and produces a clearance zone (Anastasioet al., 2010).
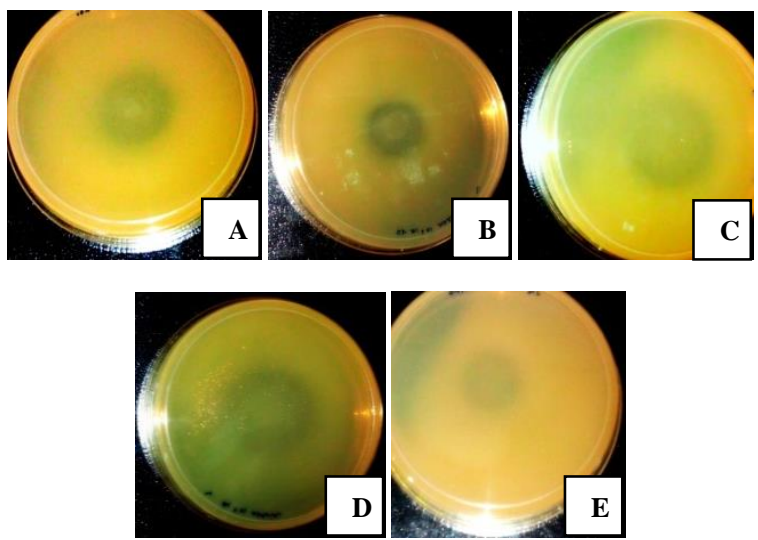

Figure 1Zone of hydrolysis of LAB A) C4/B; B) C3/1A/4Dl; C) C5/D; D) C4/1A; E) B4/E
The quantitative screening method was conducted with all the five isolates at $37^{\circ} \mathrm{C}$ by using chemical assay method. From the experiment, $\mathrm{C} 4 / 1 \mathrm{~A}$ isolate showed the highest phytase activity of $21.25 \mathrm{U} / \mathrm{mL}$ at $12 \mathrm{~h}$ of incubation time compared to other isolates as shown in Figure 2. Production of inorganic phosphate in isolates $\mathrm{C} 4 / \mathrm{B}, \mathrm{C} 3 / 1 \mathrm{~A} / 4 \mathrm{D}, \mathrm{C} 5 / \mathrm{D}$ and $\mathrm{B} 4 / \mathrm{E}$ resulted in $18.34 \mathrm{U} / \mathrm{mL}$, $14.21 \mathrm{U} / \mathrm{mL}, 14.93 \mathrm{U} / \mathrm{mL}$, and $12.49 \mathrm{U} / \mathrm{mL}$ of phytase activity at $14,12,16$, and $18 \mathrm{~h}$, respectively.

The isolate was identified as PediococcuspentosaceusC4/1A by $16 \mathrm{~S}$ rRNAsequencingas shown in Figure 3. The enzyme activity obtained was described in enzyme unit (U) and the determination of phytase activity was done using spectrophotometer at $700 \mathrm{~nm}$ to investigate the liberated amount of inorganic phosphate. From the experiment, different isolates have their own ability to degrade phytate. $P$. pentosaceus $\mathrm{C} 4 / 1 \mathrm{~A}$ degrades phytate and has the capability to reduce the phosphorus excretion by poultry to the environment. Therefore, this strain could be applied for the diet of monogastric animals (Casey and Walsh, 2004).

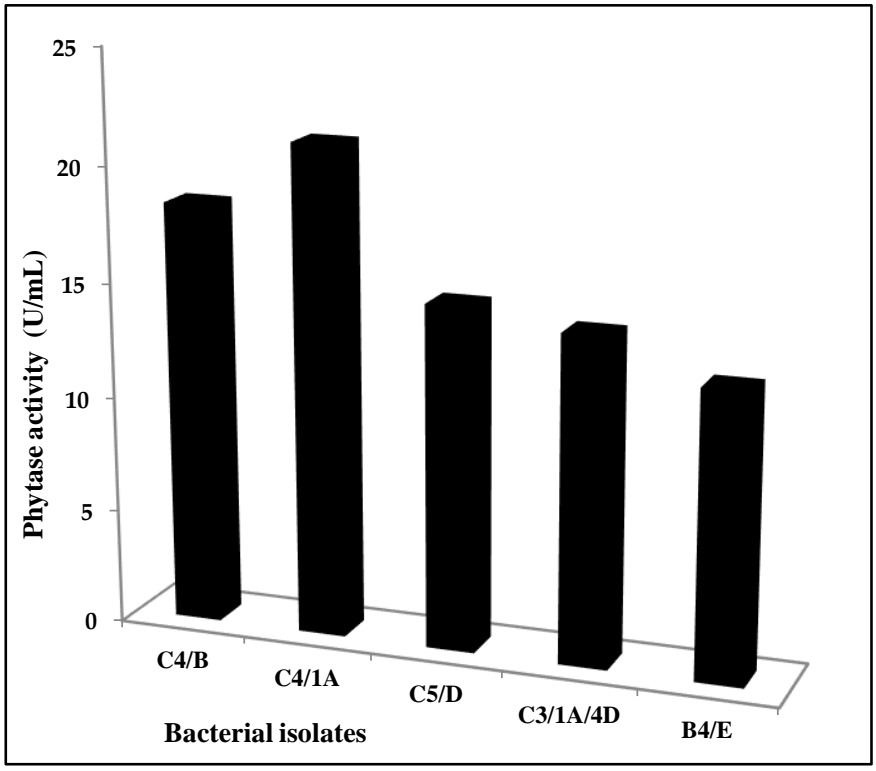

Figure 2Phytase activity of the bacterial isolates using sodium phytate as phosphate source

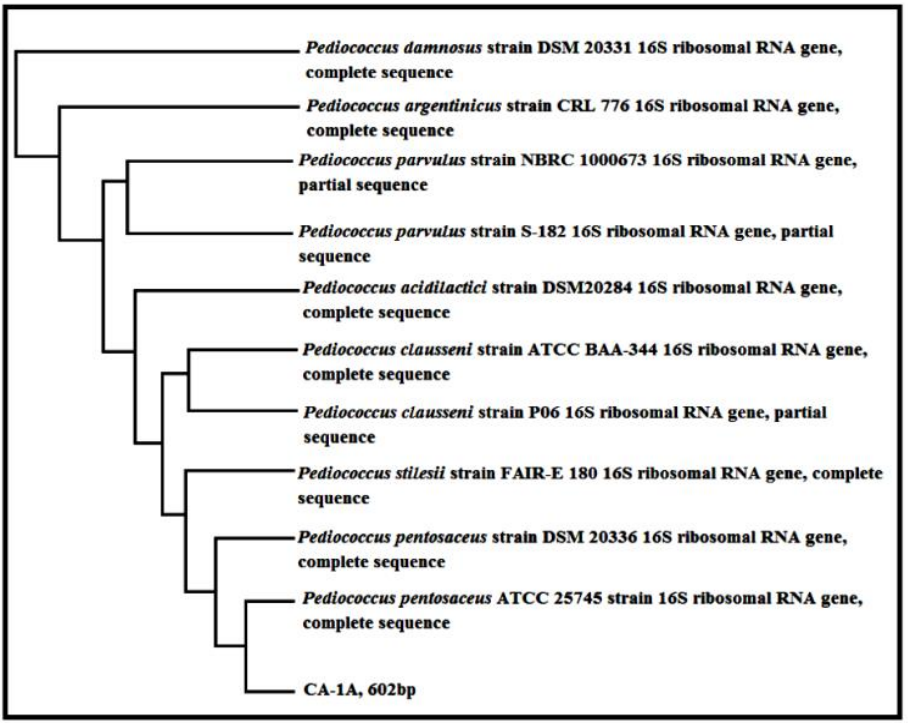

Figure 3 Phylogenetic Tree-Neighbouring joint (Unrooted Tree) by NCBI Blast Tree Method

\section{Effect of Carbon Source on Phytase Biosynthesis}

A preliminary study was done on various carbon sources to determine the better biosynthesis of phytase. Glucose, lactose and maltose were chosen in this conventional study. $P$. pentosaceus $\mathrm{C} 4 / 1 \mathrm{~A}$ was able to grow well on three carbon sources and also was able to produce phytase. Among the tested carbon sources, production of phytase was the highest in glucose $(34.17 \mathrm{U} / \mathrm{mL})$ at $16^{\text {th }} \mathrm{h}$ of 
cultivation compared to lactose and maltose. The highest productivity of phytase was achieved during the fermentation process with glucose $(2.14 \mathrm{U} / \mathrm{mL} / \mathrm{h})$ compared to lactose $(1.04 \mathrm{U} / \mathrm{mL} / \mathrm{h})$ and maltose $(1.99 \mathrm{U} / \mathrm{mL} / \mathrm{h})$. In the cultivation, carbon source does not only support in the cell growth but also in the production of the enzyme where it will be metabolized completely to produce the product (Ravinder et al., 2012).

\section{Effect of Nitrogen Source on Phytase Biosynthesis}

Among the tested nitrogen sources (yeast extract, meat extract, peptone from casein), the maximum cell concentration of $5.88 \mathrm{~g} / \mathrm{L}$ was achieved in yeas extract cultivation. Moreover, the highest phytase biosynthesis was also obtained at $10^{\text {th }} \mathrm{h}$ of fermentation when yeast extract was used $(36.22 \mathrm{U} / \mathrm{mL})$ compared to the production in meat extract $(31.65 \mathrm{U} / \mathrm{mL})$ and peptone from casein $(14.42$ $\mathrm{U} / \mathrm{mL})$ at $16^{\text {th }} \mathrm{h}$ of fermentation. Yeast extract contained a nitrogenous compound which plays a major role as the growth factor whereby it enhances the cell growth of microorganisms (Alshiyabet al., 2008).

\section{Optimization of Glucose Concentration}

Optimization of different concentration of glucose was tested. From the result obtained (Table 4), the maximum cell concentration of $6.45 \mathrm{~g} / \mathrm{L}$ was achieved. Whereas phytase production of $37.27 \mathrm{U} / \mathrm{mL}$ was achieved at $10^{\text {th }} \mathrm{h}$ of cultivation process compared to other concentrations used. Glucose is also known as metabolizable sugar compared to lactose and maltose (Sasirekha et al., 2012). It plays the major role as a nutritional factor which stimulates the biosynthesis of phytase and cell biomass (Vohra and Satyanarayana, 2003). From this study, the optimal concentration of glucose that can be applied was $15 \mathrm{~g} / \mathrm{L}$ to obtain the highest production of enzyme. As the concentration of glucose increases or decreases from the optimal concentration, the phytase production achieved was low. This is due to the formation of carbon flux in the cell which focuses on the cell growth rather than the enzyme production (Kalil et al., 2008).

Table 4 The performance and the kinetic parameter values of phytase production by PediococcuspentosaceusC4/1A using different concentration of glucose

\begin{tabular}{lcccc}
\hline Kinetic & $\mathbf{5}$ g/L & $\mathbf{1 0} \mathbf{g} / \mathbf{L}$ & $\mathbf{1 5} \mathbf{g} / \mathbf{L}$ & $\mathbf{2 0} \mathbf{g} / \mathbf{L}$ \\
\hline Parameter & 10 & 10 & 10 & 18 \\
\hline $\mathrm{h} / \mathrm{h}$ & 5.77 & 6.03 & 6.45 & 6.12 \\
$X_{\max } /(\mathrm{g}$ cell $/ \mathrm{L})$ & 32.46 & 34.17 & 37.27 & 36.89 \\
$P_{\max } /(\mathrm{U}$ phytase $/ \mathrm{mL})$ & 3.02 & 9.07 & 14.03 & 18.93 \\
$S_{i}-S_{f} /(\mathrm{g}$ substrate $/ \mathrm{L})$ & 0.216 & 0.50 & 0.32 & 0.291 \\
$\mu / \mathrm{h}^{-1}$ & 1.91 & 0.66 & 0.460 & 0.323 \\
$Y_{x / s} /(\mathrm{g}$ cell $/ \mathrm{g}$ substrate $)$ & 10.74 & 3.76 & 2.65 & 1.94 \\
$Y_{p / s} /(\mathrm{U}$ of phytase $/ \mathrm{g}$ & 5.61 & 5.66 & 5.77 & 6.02 \\
substrate $)$ & 3.25 & 2.14 & 3.73 & 2.05 \\
$Y_{p / x} /(\mathrm{U}$ phytase $/ \mathrm{g}$ cell $)$ & & & & \\
$P_{r} /(\mathrm{U}$ phytase $/(\mathrm{mL} . \mathrm{h}))$ & & &
\end{tabular}

\section{Optimization of Yeast Extract}

Effect of different concentration of yeast extract was tested in this study. Highes phytase production was achieved at concentration of $20 \mathrm{~g} / \mathrm{L}$ which was 41.04 $\mathrm{U} / \mathrm{mL}$, followed by $25 \mathrm{~g} / \mathrm{L}(37.17 \mathrm{U} / \mathrm{mL}), 10 \mathrm{~g} / \mathrm{L}(36.42 \mathrm{U} / \mathrm{mL}), 15 \mathrm{~g} / \mathrm{L}(36.22$ $\mathrm{U} / \mathrm{mL})$ and $5 \mathrm{~g} / \mathrm{L}(32.97 \mathrm{U} / \mathrm{mL})$. Table 5 shows the kinetic parameter values of $P$. pentosaceusC4/1 A cultivations using the different concentration of yeast extract. Highest cell concentration obtained was $7.188 \mathrm{~g} / \mathrm{L}$. The cell growth does not correlate when the nitrogen source increases in the fermentation as it causes inhibition of growth. Besides, the highest productivity $(3.62 \mathrm{U} / \mathrm{mL} / \mathrm{h})$ was achieved in $15 \mathrm{~g} / \mathrm{L}$ of yeast extract in the medium.

Table 5 The performance and the kinetic parameter values of phytase production by PediococcuspentosaceusC4/1A using different concentration of yeast extract

\begin{tabular}{|c|c|c|c|c|c|}
\hline $\begin{array}{l}\text { Kinetic } \\
\text { Parameter }\end{array}$ & $5 \mathrm{~g} / \mathrm{L}$ & $10 \mathrm{~g} / \mathrm{L}$ & $15 \mathrm{~g} / \mathrm{L}$ & $20 \mathrm{~g} / \mathrm{L}$ & $25 \mathrm{~g} / \mathrm{L}$ \\
\hline $\mathrm{t} / \mathrm{h}$ & 16 & 18 & 10 & 12 & 16 \\
\hline$X_{\max } /(\mathrm{g}$ cell $/ \mathrm{L})$ & 6.51 & 6.72 & 5.88 & 7.188 & 6.05 \\
\hline$P_{\max } /(\mathrm{U}$ phytase $/ \mathrm{mL})$ & 32.97 & 36.42 & 36.22 & 41.04 & 37.17 \\
\hline$S_{i}-S_{f} /(\mathrm{g}$ substrate $/ \mathrm{L})$ & 9.18 & 9.03 & 9.34 & 9.45 & 9.38 \\
\hline$\mu / \mathrm{h}^{-1}$ & 0.27 & 0.225 & 0.413 & 0.158 & 0.184 \\
\hline$Y_{x / s} /(\mathrm{g}$ cell $/ \mathrm{g}$ substrate $)$ & 0.71 & 0.743 & 0.630 & 0.76 & 0.659 \\
\hline $\begin{array}{l}Y_{p / s} /(\mathrm{U} \text { of phytase } / \mathrm{g} \\
\text { substrate) }\end{array}$ & 3.59 & 4.03 & 3.87 & 4.34 & 4.05 \\
\hline$Y_{p / x} /(\mathrm{U}$ phytase/g cell $)$ & 5.05 & 5.41 & 6.15 & 5.70 & 6.15 \\
\hline$P_{r} /(\mathrm{U}$ phytase $/(\mathrm{mL} \cdot \mathrm{h}))$ & 2.06 & 2.02 & 3.62 & 3.42 & 2.32 \\
\hline
\end{tabular}

Optimization of Sodium Phytate

The addition of sodium phytate as a phosphate source in medium helps the process of phytate hydrolysis (Palacios et al., 2008). Maximum phytase production of $27.42 \mathrm{U} / \mathrm{mL}$ was observed in $5 \mathrm{~g} / \mathrm{L}$ concentration of sodium phytate. However, the higher the concentration of sodium phytate used the production of phytase decreases as shown in Table 6. As for the growth yield, $Y_{x / s}$, in the concentration of $10 \mathrm{~g} / \mathrm{L}$, sodium phytate was consumed more for the cell growth rather than phytase biosynthesis. This increases the cell concentration of $5.71 \mathrm{~g} / \mathrm{L}$ compared to others. The concentration of phytate is an important factor which determines the phytase biosynthesis. The higher the concentration of phytate, more cations are prone to chelation and prevents the metabolism of an organism (Maga, 1982; Soni and Khire, 2007).

Table 6 The performance and the kinetic parameter values of phytase production by PediococcuspentosaceusC4/1A using different concentration of sodium phytate

\begin{tabular}{lccccc}
\hline Kinetic Parameter & $\mathbf{4} \mathbf{g} / \mathbf{L}$ & $\mathbf{5 ~ g / L}$ & $\mathbf{1 0} \mathbf{g} / \mathbf{L}$ & $\mathbf{1 5} \mathbf{g} / \mathbf{L}$ & $\mathbf{2 0} \mathbf{g} / \mathbf{L}$ \\
\hline $\mathrm{t} / \mathrm{h}$ & 16 & 16 & 12 & 10 & 10 \\
$X_{\max } /(\mathrm{g}$ cell $/ \mathrm{L})$ & 5.23 & 5.62 & 5.71 & 5.64 & 5.63 \\
$P_{\max } /(\mathrm{U}$ phytase $/ \mathrm{mL})$ & 24.75 & 27.42 & 23.90 & 22.58 & 19.15 \\
$S_{i}-S_{f} /(\mathrm{g}$ substrate $/ \mathrm{L})$ & 9.18 & 9.38 & 7.59 & 9.03 & 8.65 \\
$\mu / \mathrm{h}^{-1}$ & 0.28 & 0.34 & 0.464 & 0.385 & 0.42 \\
$Y_{x / s} /(\mathrm{g}$ cell $/ \mathrm{g}$ substrate $)$ & 0.556 & 0.599 & 0.752 & 0.624 & 0.650 \\
$Y_{p / s} /(\mathrm{U}$ of phytase $/ \mathrm{g}$ & 2.73 & 2.92 & 3.14 & 2.50 & 2.21 \\
substrate $)$ & & 4.87 & 4.18 & 4.00 & 3.40 \\
$Y_{p / x} /(\mathrm{U}$ phytase $/ \mathrm{g}$ cell $)$ & 4.91 & 1.71 & 1.99 & 2.26 & 1.92 \\
$P_{r} /(\mathrm{U}$ phytase $/(\mathrm{mL} . \mathrm{h}))$ & 1.55 & & & &
\end{tabular}

\section{Optimization of Inoculum Size}

Production of the enzyme in fermentation process depends on the size of inoculum being used. In this study, $4 \%, 5 \%, 10 \%, 15 \%$ as $20 \%(\mathrm{v} / \mathrm{v})$ of inoculum were used. Overall, $5 \%$ of inoculum has achieved the highest production of phytase $(25.20 \mathrm{U} / \mathrm{mL})$ as shown in Table 7 . As inoculum size increases, production of phytase decreases due to the nutrient limitation which results in higher biomass production, hence, decreasing the metabolic activity. Production of phytase and cell biomass according to this study indicates a strong non-growth associated phytase production which does not show correlation with inoculum size.

Table 7 The performance and the kinetic parameter values of phytase production by PediococcuspentosaceusC4/1A using different concentration of inoculum size \begin{tabular}{lccccc}
\hline Kinetic Parameter & $\mathbf{4 \%}$ & $\mathbf{5 \%}$ & $\mathbf{1 0 \%}$ & $\mathbf{1 5 \%}$ & $\mathbf{2 0 \%}$ \\
\hline $\mathrm{t} / \mathrm{h}$ & 8 & 10 & 10 & 12 & 14
\end{tabular}

t/h $\quad 8 \%=10=14$

$X_{\max } /(\mathrm{g}$ cell/L)

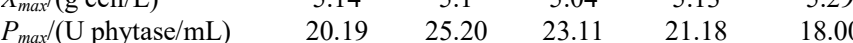

$\begin{array}{llllll}S_{i}-S_{f}(\text { g substrate } / \mathrm{L}) & 8.46 & 9.18 & 9.32 & 7.06 & 9.06\end{array}$

$\begin{array}{llllll}\mu / \mathrm{h}^{-1} & 0.44 & 0.494 & 0.43 & 0.44 & 0.453\end{array}$

$\begin{array}{llllll}Y_{x / s} /(\mathrm{g} \text { cell } / \mathrm{g} \text { substrate }) & 0.608 & 0.555 & 0.540 & 0.727 & 0.584\end{array}$

$\begin{array}{llllll}Y_{p / s} /(\mathrm{U} \text { of } \text { phytase/g } & 2.39 & 2.74 & 2.47 & 3.00 & 1.98\end{array}$ substrate)

$\begin{array}{llllll}Y_{p / x} /(\mathrm{U} \text { phytase/g cell }) & 3.93 & 4.94 & 4.58 & 4.12 & 3.39\end{array}$

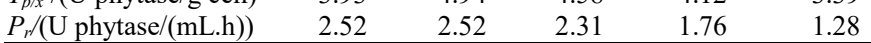

\section{RSM Modelling}

Central Composite Design (CCD) used in this study with 30 run of experiments on the maximum production of phytase at $16 \mathrm{~h}$ of fermentation was validated with the value predicted by the model in which inoculum size $10 \%(\mathrm{v} / \mathrm{v})$, sodium phytate $11.8 \mathrm{~g} / \mathrm{L}$, yeast extract $17.2 \mathrm{~g} / \mathrm{L}$ and glucose $16.2 \mathrm{~g} / \mathrm{L}$ were obtained. The final equation in terms of actual factors for production of phytase best predicted by the models:

$\mathrm{Y}=32.96-2.72 \mathrm{~A}-0.58 \mathrm{~B}+0.11 \mathrm{~A}^{2}+2.26 \mathrm{~B}^{2}$

$-6.42 \mathrm{C}^{2}-4.84 \mathrm{D}^{2}-0.36 \mathrm{AB}+0.39 \mathrm{AC}$

$+0.54 \mathrm{AD}-0.86 \mathrm{BC}+0.62 \mathrm{BD}+0.77 \mathrm{CD}$

Where $\mathrm{Y}$ is enzyme activity $(\mathrm{U} / \mathrm{mL})$; $\mathrm{A}$ is inoculum size $(\%)$; B is substrate $(\mathrm{g} / \mathrm{L})$; $\mathrm{C}$ is yeast extract $(\mathrm{g} / \mathrm{L})$; D is glucose $(\mathrm{g} / \mathrm{L})$.

According to the experimental design used, the result was analyzed by using analysis of variance (ANOVA). Several criteria can be used to check the goodness of the model. The value of $\mathrm{R}^{2}$ was 0.9917 for phytase production which explains that $99 \%$ of variation is explained by the model. The value of $\mathrm{R}^{2}$ that is closer to 1.0 indicates the stronger and suitability of the model. The correlation coefficient (predicted $\mathrm{R}^{2}$ ) has the value of 0.9509 . This indicates that $95 \%$ of experimental data was compatible with predicted data by the model. The value of adjusted $\mathrm{R}^{2}(0.9840)$ determines the significance of the model. The model Fvalue of 128.62 implies the model is significant. Values of "prob> F" less than 0.0500 indicate model terms are significant. In this case $\mathrm{A}, \mathrm{B}, \mathrm{A}^{2}, \mathrm{~B}^{2}, \mathrm{C}^{2}, \mathrm{D}^{2}, \mathrm{AB}$, $\mathrm{AC}, \mathrm{AD}, \mathrm{BC}, \mathrm{BD}$ and $\mathrm{CD}$ are significant model terms. Values greater than 0.1000 indicate the model terms are not significant. The "Lack of fit F-value" of 2.77 implies the Lack of fit is not significant relative to the pure error. The value 
of adequate precision greater than 4 is desirable whereby the ratio of 41.995 indicates an adequate signal. Validation of the experimental model was done by the statistical model by choosing the maximum production of phytase as the desired result. Highest production of phytase activity $(42.3 \mathrm{U} / \mathrm{mL})$ was achieved through validation of the model under the optimized conditions. During the optimization, phytase production has increased two-fold compared to the initial non-optimized conditions. It has shown improvement of $99.5 \%$ from 21.25 $\mathrm{U} / \mathrm{mL}$ to $42.3 \mathrm{U} / \mathrm{mL}$

Figure 4 shows the three-dimensional surface of independent factors, inoculum size, substrate, yeast extract and glucose as a response to phytase production. The analysis indicates there are interactions between these four variables. Production of phytase can be maximized with the presence of independent variables where it appears to be significant model. However, phytase production was not favorable with the presence of yeast extract and glucose alone. This analysis depicts that, there is a need of interaction between independent variables to maximize the phytase production in two-fold.
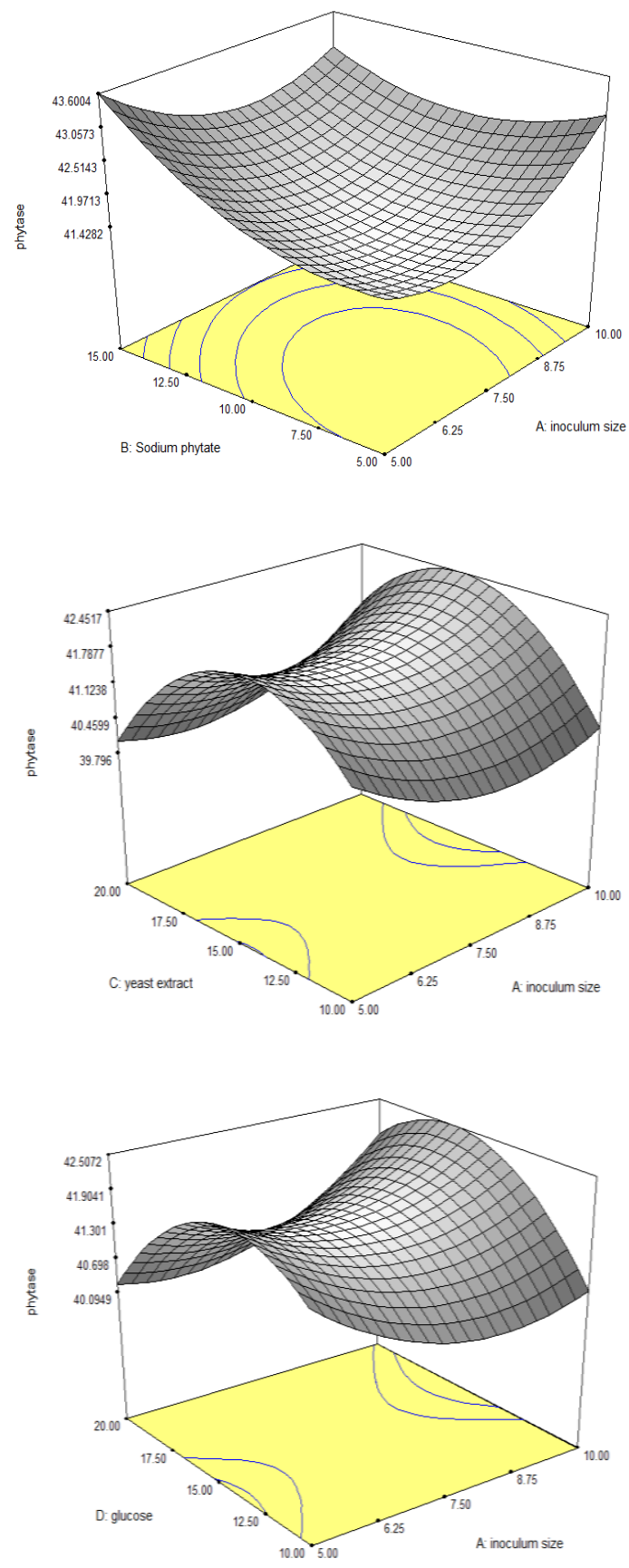
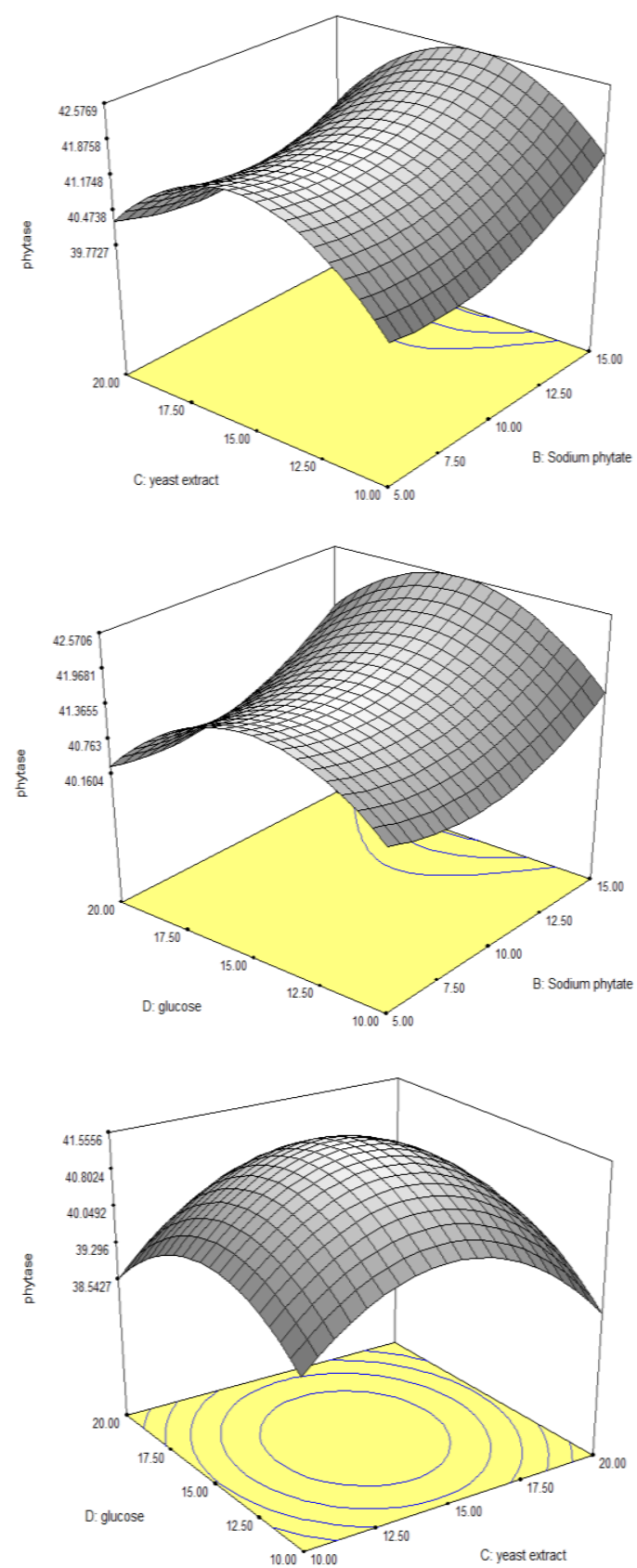

Figure 4 Three-dimensional surface of independent factors.

Validation of analysis of variance from the experiment was done by the statistical model by choosing the maximum production of phytase as the desired result. Highest production of phytase activity $(42.3 \mathrm{U} / \mathrm{mL})$ was achieved from triplicate experiments through validation of the model under the optimized conditions as shown in Table 8. During optimization, phytase production has increased twofold compared to the initial non-optimized conditions. It has showed improvement of $99.2 \%$ from $21.24 \mathrm{U} / \mathrm{mL}$ to $42.3 \mathrm{U} / \mathrm{mL}$. It was the suitable concentration of medium formulation since the biosynthesis of phytase by $P$. pentosaceus $4 / 1 \mathrm{~A}$ was at maximum. Media used during cultivation allowed the bacteria to grow well, helps in the energy metabolism and maintain the culture. The factors also play the role for the improvement of phytase production.

Table 8 Validated medium for phytase production

\begin{tabular}{lc}
\hline Media Composition & Concentrations \\
\hline $\mathrm{D}(+)$ Glucose & $16.2(\mathrm{~g} / \mathrm{L})$ \\
Yeast Extract & $17.2(\mathrm{~g} / \mathrm{L})$ \\
Sodium Phytate & $11.8(\mathrm{~g} / \mathrm{L})$ \\
Inoculum size & $10 \%(\mathrm{v} / \mathrm{v})$ \\
Tween 80 & $1(\mathrm{~mL} / \mathrm{L})$ \\
di-ammonium hydrogen citrate & $2(\mathrm{~g} / \mathrm{L})$ \\
Sodium Acetate & $5(\mathrm{~g} / \mathrm{L})$ \\
Magnesium Sulfate & $0.2(\mathrm{~g} / \mathrm{L})$ \\
Magnesium Sulfate & $0.04(\mathrm{~g} / \mathrm{L})$ \\
\hline
\end{tabular}




\section{Continuous Cultivation}

In continuous cultivation, the rate of medium flow into the vessel is related to its culture volume as explained by the dilution rate $(D)\left(h^{-1}\right)$. It is defined as $D=F / V$, where $\mathrm{F}$ is the flow rate $(\mathrm{mL} / \mathrm{h})$ and $\mathrm{V}$ is the culture volume $(\mathrm{mL})$. Fresh medium was fed continuously into the vessel for the formation of new biomass and it was balanced by the loss of cells out of the vessel simultaneously. At this point, steady-state could be achieved. Continuous cultivation undergoes exponentia phase which will be prolonged throughout the period unlike batch cultivation (Myers et al., 2009c).

Productivity of phytase and cell concentration in Figure 5 was obtained during steady-state by using various dilution rates. Cell growth in the steady-state is maintained during cultivation and achieved when there is less fluctuation in nutrients. The flow of the fresh medium into the vessel equals the flow of the cells out of the vessel. As shown in Table 9, the result for the productivity of phytase and cell concentration shows variation to all the four dilution rates used. As dilution rate increases until $0.3 \mathrm{~h}^{-1}$, the enzyme production, and cell biomas reached its maximum level before it drops at dilution rate $0.4 \mathrm{~h}^{-1}$. Specific growth rate of a culture usually determined by the dilution rate used (Tan, 2016b) However, in this study, less productivity achieved at dilution rate $0.4 \mathrm{~h}^{-1}$ for phytase $(4.16 \mathrm{U} / \mathrm{mL} / \mathrm{h})$ and cell concentration $(0.399 \mathrm{~g} / \mathrm{L} / \mathrm{h})$. It is when the fresh medium was added to the vessel and cells were removed from the vessel exceeds the maximum specific growth rate of $P$. pentosaceus $4 / 1 \mathrm{~A}$, which results in the decrease of cell biomass and enzyme production in the bioreactor. Eventually, the number of cells became zero at the end of cultivation.

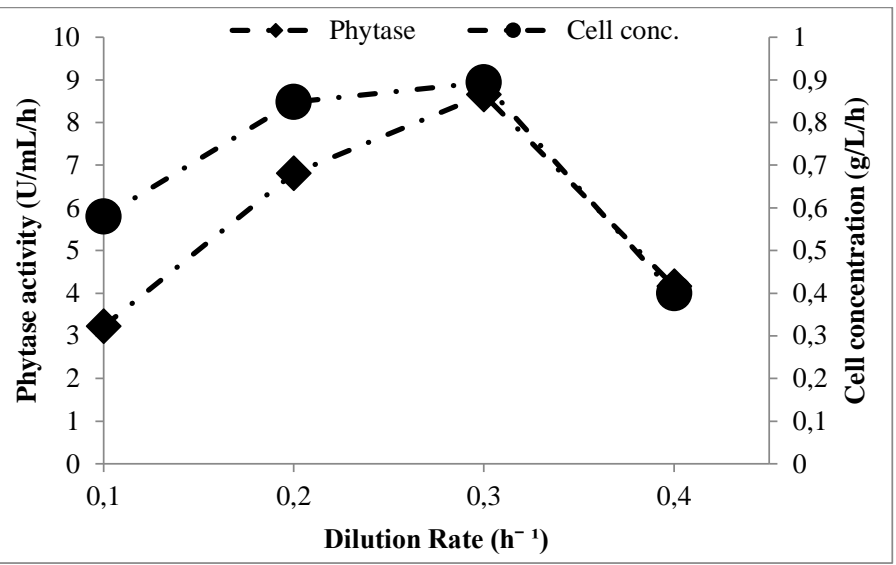

Figure 5 Productivity of $P$. pentosaceusC4/1A at different dilution rate

Table 9 Productivity of phytase and cell concentration in continuous cultivation by P. PentosaceusC4/1A

\begin{tabular}{ccc}
\hline Dilution rate $\left(\mathbf{h}^{-\mathbf{1}}\right)$ & $\begin{array}{c}\text { Phytase productivity } \\
(\mathbf{U} / \mathbf{m L . h})\end{array}$ & $\begin{array}{c}\text { Cell concentration } \\
(\mathbf{g} / \mathbf{L} . \mathbf{h})\end{array}$ \\
\hline 0.1 & 3.223 & 0.579 \\
0.2 & 6.806 & 0.848 \\
0.3 & 8.652 & 0.894 \\
0.4 & 4.16 & 0.399 \\
\hline
\end{tabular}

This study demonstrated that cultivation of $P$. pentosaceusC4/1A in $2 \mathrm{~L}$ stirred tank bioreactor could improve the productivity of phytase for mass production. The optimized medium formulation was applied in batch cultivation and continuous cultivation mainly to obtain high productivity of phytase. Biosynthesis of phytase has increased by $89.3 \%$ from shake-flask experiment to $2 \mathrm{~L}$ bioreactor. Whereas in continuous cultivation, highest productivity of enzyme was achieved at a dilution rate of $0.3 \mathrm{~h}^{-1}$ which resulted in $8.652 \mathrm{U} / \mathrm{mL} / \mathrm{h}$ where it increases up to almost $100 \%$ compared to shake-flask culture.

\section{CONCLUSION}

Results from this study have demonstrated that LAB was able to grow well on MRS medium and produce phytase. The highest phytase was produced by $P$. PentosaceusC4/1A using modified MRS medium. RSM was used as a statistica tool to improve the biosynthesis of phytase with the combination of inoculum size $(10 \%)$, sodium phytate $(11.8 \mathrm{~g} / \mathrm{L})$, yeast extract $(17.2 \mathrm{~g} / \mathrm{L})$ and glucose $(16.2$ $\mathrm{g} / \mathrm{L})$. Higher productivity of phytase was achieved $(8.652 \mathrm{U} / \mathrm{mL} / \mathrm{h})$ by $P$. PentosaceusC4/1A using continuous cultivation in $2 \mathrm{~L}$ stirred tank bioreactor with dilution rate on $0.3 \mathrm{~h}^{-1}$.

Acknowledgements: The study was supported by the Graduate Research Fund (GRF) Universiti Putra Malaysia, My Master scholarship and LRGS Grant from the Ministry of Education Malaysia, vote number: 5526009

\section{REFERENCES}

Alshiyab, H. Kalil, M.S. Hamid, A.A. \&Yusoff, W.M. (2008).Effect of some environmental parameters on hydrogen production using $C$. acetobutylicum.Pakistan journal of Biological Sciences: PJBS,11: 20732082.https://doi.org/10.3923/pjbs.2008.2073.2082

Ammor, M. S., BelénFlórez, A., \& Mayo, B. (2007).Antibiotic resistance in nonenterococcal lactic acid bacteria and bifidobacteria.Food Microbiology, 24(6), 559-570. https://doi.org/10.1016/j.fm.2006.11.001

Anastasio, M., Pepe, O., Cirillo, T., Palomba, S., Blaiotta, G., \&Villani, F. (2010).Selection and Use of Phytate-Degrading LAB to Improve Cereal-Based Products by Mineral Solubilization during Dough Fermentation.Journal of Food Science,75(1), M28-M35.

https://doi.org/10.1111/j.1750-3841.2009.01402.x

Bae, H.D., Yanke, L.J., Cheng, K.-J., \&Selinger, L.B. (1999).A novel staining method for detecting phytaseactivity.Journal of Microbiological Methods, 39(1), 17-22. https://doi.org/10.1016/s0167-7012(99)00096-2

Bohn, L., Meyer, A. S., \& Rasmussen, S. K. (2008).Phytate: impact on environment and human nutrition. A challenge for molecular breeding.Journal of Zhejiang University SCIENCEB, 9(3), 165-191.

https://doi.org/10.1631/jzus.b0710640

Box, G.E. Wilson, K.B. (1951).On the experimental attainment of optimum conditions. Journal of the Royal Statistical Society Series B Statistical Methodology, 13, 1-45.

Casey, A. and Walsh, G., (2004).Identification and characterization of a phytase of potential commercial interest.Journal of Biotechnology, 110(3), 313 322.https://doi.org/10.1016/s0168-1656(04)00156-7

CatarinaGuedes, A., Katkam, N. G., Varela, J., \& Xavier Malcata, F. (2013).Photobioreactors for cyanobacterialculturing.Cyanobacteria: Journal of EconomicPerspectives, 270-292.

https://doi.org/10.1002/9781118402238.ch17

De Angelis, M. Gallo, G. Corbo, M.R. McSweeney, P.L. Faccia, M. Giovine, M. and Gobbetti, M., (2003a).Phytase activity in sourdough lactic acid bacteria: purification and characterization of a phytase from Lactobacillus sanfranciscensis CB1.International Journal of Food Microbiology,87(3), 259270. https://doi.org/10.1016/s0168-1605(03)00072-2

De Angelis, M. Gallo, G. Corbo, M.R. McSweeney, P.L. Faccia, M. Giovine, M. and Gobbetti, M., (2003b).Phytase activity in sourdough lactic acid bacteria: purification and characterization of a phytase from Lactobacillus sanfranciscensis CB1.International Journal of Food Microbiology,87(3), 259 270. https://doi.org/10.1016/s0168-1605(03)00072-2

Greiner, R., Farouk, A.-E., Carlsson, N.-G., \&Konietzny, U. (2007).Myo-inositol phosphate isomers generated by the action of a phytase from a Malaysian wastewater bacterium.The Protein Journal, 26(8), 577-584 https://doi.org/10.1007/s10930-007-9100-5

Haefner, S., Knietsch, A., Scholten, E., Braun, J., Lohscheidt, M., \&Zelder, O. (2005).Biotechnological production and applications of phytases.Applied Microbiology and Biotechnology,68(5), 588-597. https://doi.org/10.1007/s00253-005-0005-y

Holzapfel, W.H. Haberer, P. Geisen, R. Björkroth, J. \&Schillinger, U. (2001).Taxonomy and important features of probiotic microorganisms in food and nutrition.TheAmerican Journal of Clinical Nutrition, 73(2), 365s-373s.

Joint, F.A.O. (2002).WHO working group report on drafting guidelines for the evaluation of probiotics in food.London, Ontario, Canada, 2002:30

Kalil, M. S., Alshiyab, H. S., \&Yusoff, W. M. W. (2008).Effect of nitrogen source and carbon to nitrogen ratio on hydrogen production using $C$ acetobutylicum.American Journal of Biochemistry and Biotechnology, 4(4), 393 401. https://doi.org/10.3844/ajbbsp.2008.393.401

Lazarte, C. E., Carlsson, N.-G., Almgren, A., Sandberg, A.-S., \&Granfeldt, Y (2015).Phytate, zinc, iron and calcium content of common Bolivian food, and implications for mineral bioavailability. Journal of Food Composition and Analysis, 39, 111-119. https://doi.org/10.1016/j.jfca.2014.11.015

Lönnerdal, B.(2002).Phytic acid-trace element $(\mathrm{Zn}, \quad \mathrm{Cu}, \quad \mathrm{Mn})$ interactions.International Journal of Food Science \&Technology,37(7), 749-758 https://doi.org/10.1046/j.1365-2621.2002.00640.x

Lopez, H. W., Leenhardt, F., Coudray, C., \&Remesy, C. (2002).Minerals and phytic acid interactions: is it a real problem for human nutrition? International Journal of Food Science and Technology, 37(7), 727-739. https://doi.org/10.1046/j.1365-2621.2002.00618.x

Lowry, O.H. Rosebrough, N.J. Farr, A.L. Randall, R.J. \& others.(1951). Protein measurement with the Folin phenol reagent.Journal of Biological Chemistry, 193(1), 265-275.

Maga, J.A. (1982).Phytate: its chemistry, occurrence, food interactions, nutritional significance, and methods of analysis. Journal of Agricultural and Food Chemistry, 30(1), 1-9.https://doi.org/10.1021/jf00109a001

Marlida, Y., Delfita, R., Adnadi, P., \&Ciptaan, G. (2010).Isolation, characterization and production of phytase from endophytic fungus its application for feed.Pakistan Journal of Nutrition, 9(5), 471474.https://doi.org/10.3923/pjn.2010.471.474 
Mittal, A. Singh, G. Goyal, V. Yadav, A. \&Aggarwal, N.K. (2012a). Production OfPhytase By Acido-Thermophilic Strain Of Klebsiella Sp. Db-3fj711774. 1 Using Orange Peel Flour Under Submerged Fermentation. nnovative Romanian Food Biotechnology, 2012;10:18.

Mittal, A. Singh, G. Goyal, V. Yadav, A. \&Aggarwal, N.K. (2012b). Production OfPhytase By Acido-Thermophilic Strain Of Klebsiella Sp. Db-3fj711774. 1 Using Orange Peel Flour Under Submerged Fermentation. nnovative Romanian Food Biotechnology, 2012;10:18.

McNeil, B., \& Harvey, L. M. (Eds.).(2008).Practical fermentation technology.Wiley Online Library.https://doi.org/10.1002/9780470725306

Miller, G. L., Blum, R., Glennon, W. E., \& Burton, A. L. (1960).Measurement of carboxymethylcellulaseactivity.AnalyticalBiochemistry, $\quad$ l(2), $\quad 127-$ 132.https://doi.org/10.1016/0003-2697(60)90004-x

Monod, J. (1950).Continuous culture technique: theory and applications.Annales De I'InstitutPasteur 1950; 79:410-590.

Myers, R.H. Montgomery, D.C. \& Anderson-Cook, C.M. (2009a).Response surface methodology: process and product optimization using designed experiments (Vol. 705). John Wiley \& Sons; 2009.Pp. 705.

Myers, R.H. Montgomery, D.C. \& Anderson-Cook, C.M. (2009b).Response surface methodology: process and product optimization using designed experiments (Vol. 705). John Wiley \& Sons; 2009.Pp. 705.

Myers, R.H. Montgomery, D.C. \& Anderson-Cook, C.M. (2009c).Response surface methodology: process and product optimization using designed experiments (Vol. 705). John Wiley \& Sons; 2009.Pp. 705.

Novick, A. \& Szilard, L. (1950).Description of the chemostat.Science, 112(2920), 715-716.https://doi.org/10.1126/science.112.2920.715

Palacios, M. C., Haros, M., Sanz, Y., \&Rosell, C. M. (2008).Selection of lactic acid bacteria with high phytate degrading activity for application in whole wheat bread making.LWT-Food Science Technology, 41(1), 82-92. https://doi.org/10.1016/j.lwt.2007.02.005

Papagianni, M. (2012).Metabolic engineering of lactic acid bacteria for the production of industrially important compounds.Computational and Structural Biotechnology Journal, 3(4), 1-8.https://doi.org/10.5936/csbj.201210003

Raghavendra, P., \&Halami, P. M. (2009a).Screening, selection and characterization of phytic acid degrading lactic acid bacteria from chicken intestine.International Journal of Food Microbiology,133(1),129-134 https://doi.org/10.1016/j.ijfoodmicro.2009.05.006

Raghavendra, P., \&Halami, P. M. (2009b).Screening, selection an characterization of phytic acid degrading lactic acid bacteria from chicken intestine.International Journal of Food Microbiology,133(1),129-134. https://doi.org/10.1016/j.ijfoodmicro.2009.05.006

Raghavendra, P., \&Halami, P. M. (2009c).Screening, selection and characterization of phytic acid degrading lactic acid bacteria from chicken intestine.International Journal of Food Microbiology,133(1),129-134. https://doi.org/10.1016/j.ijfoodmicro.2009.05.006

Raghavendra, P., \&Halami, P. M. (2009d).Screening, selection and characterization of phytic acid degrading lactic acid bacteria from chicken intestine.International Journal of Food Microbiology,133(1),129-134. https://doi.org/10.1016/j.ijfoodmicro.2009.05.006

Ravinder, K. Prabhakar, T. \&Bhavanidevi, R., (2012).Optimization of process parameters for the production of cyclodextringlycosyltransferase by newly isolated bacillus sp. Tpr71h by conventional method.International Journal of Advanced Biotechnology and Research, 3(2), 578-584.

Roy, T., Mondal, S., \& Ray, A. K. (2009).Phytase-producing bacteria in the digestive tracts of some freshwater fish.Aquaculture Research, 40(3), 344-353.

https://doi.org/10.1111/j.1365-2109.2008.02100.x

Sasirekha, B. Bedashree, T. \&Champa, K.L., (2012).Optimization and partial purification of extracellular phytase from Pseudomonas aeruginosa p6.European Journal of Experimental Biology, 2(1), 95-104

Savadogo, A. Ouattara, A.C. Bassole, H.I. \&Traore, S.A., (2006).Bacteriocins and lactic acid bacteria-a minireview. African Journal of Biotechnology, 5(9).Retrieved from http://www.ajol.info/index.php/ajb/article/view/42771.

Soni, S. K., \&Khire, J. M. (2007).Production and partial characterization of two types of phytase from Aspergillusniger NCIM 563 under submerged fermentation conditions.World Journal of Microbiology and Biotechnology,23(11), 15851593.https://doi.org/10.1007/s11274-007-9404-9

Tan Wei L., (2016a).Fermentation of Palm Kernel Cake by Indigenous Lactic Acid Bacteria as Potential Poultry Feed Ingredients, Master Thesis, Universiti Putra Malaysia.

Tan Wei L., (2016b).Fermentation of Palm Kernel Cake by Indigenous Lactic Acid Bacteria as Potential Poultry Feed Ingredients, Master Thesis, Universiti Putra Malaysia.

Vohra, A., \&Satyanarayana, T. (2001).Phytase production by the yeast,Pichiaanomala. Biotechnology Letters, 23(7), 551-554. https://doi.org/10.1023/a:1010314114053

Vohra, A., \&Satyanarayana, T. (2003).Phytases: microbial sources, production, purification, and potential biotechnological applications. Critical Review Biotechnology, 23(1), 29-60.https://doi.org/10.1080/713609297
Yanke, L. J., Bae, H. D., Selinger, L. B., \& Cheng, K. J. (1998).Phytase activity of anaerobic ruminal bacteria.Microbiology.1998,144:6:15651573.https://doi.org/10.1099/00221287-144-6-1565

Zhang, G.-Q., Wu, Y.-Y., Ng, T.-B., Chen, Q.-J., \& Wang, H.-X. (2013).A phytase characterized by relatively high $\mathrm{pH}$ tolerance and thermostability from the Shiitake mushroom Lentinusedodes. BioMed research international, 2013. https://doi.org/10.1155/2013/540239 